\title{
Needs Assessment of the University's Greening Management Program
}

\author{
Mauro Allan P. Amparado \\ Director, Community Awareness, Relations \& Extension Services \\ mapamparado@gmail.com \\ Kenneth Y. Moralde \\ Program CARES Coordinator, Elementary Department \\ Julienutrie A. Sumalinog \\ Program CARES Coordinator, Junior High School Department

\begin{abstract}
University of Cebu Lapu-Lapu and Mandaue
Mandaue City, Cebu, Philippines
\end{abstract}

\section{Abstract}

This study is a needs assessment of the greening management program which will be implemented as a community extension program in the Basic Education Department of UCLM. The study utilized the descriptive quantitative design using researcher-made questionnaires. Perceptions from students were gathered using a survey form. The study was conducted at the Basic Education Department of UCLM. Two hundred elementary students and two hundred junior high school students were surveyed. For the treatment of the data, frequency, proportion and weighted mean was used.

Based on the findings from the Elementary Department, majority of the respondents has not planted in the last 12 months. But they would like to participate in a greening management program. The students would like to do the following: plant vegetables; take care of fruit-bearing tree seedlings; and take care of plants (cultivating, watering, fencing, controlling of pests, 
weeding and fertilizing). They would like to do gardening activities from 12:30 PM to 1:30 PM.

For vegetables, they would like to plant talong, sili and monggo. For fruit-bearing plants, they would like to plant mango, avocado and water apple tree. For ornamental plants, they would like to plant rose, gumamela and orchids.

Among the junior high school respondents, majority of the respondents were: aware about the issue on climate change; want to become part in the solution of the problem; aware about the greening program; have plants at home; aware that greening management conserves natural resources and the ecosystem; will participate in the greening program; they segregate wastes at home and in the school; have seen students planting in school; aware of organic fertilizers; and are aware of indigenous plants.

However, it was worthy to note that the students: were not involved in planting activities in the last 12 months; have not seen their teachers in planting activities in school; and are not aware of permaculture. The students rate the present greening status of the department and the university as good. The students would like to plant calamansi. They can afford to take care two plants. They prefer to take care of their plants from 6:00 AM to 7:00 AM.

Based on the findings of the study, the students of the Basic Education Department accept the greening management program and are willing to participate in this program.

Keywords: Greening Management Program, Mango, Calamansi, Rose, Organic fertilizers, waste segregation

Recommended citation: Amparado, M. A. P., Moralde, K. Y. \& Sumalinog, J. A. (2020). Needs Assessment of the University's 
Greening Management Program. Cebu Journal of Teacher Education, 1(2), 85-100.

\section{Introduction}

As a person becomes involved with the preservation of the natural environment, he/she should recognize the main global environmental problems and how these problems are changing. The list of environmental problems is long. Some of the more serious ones include natural resource depletion, global warming, pollution (air, water, and soil), industrial accidents, and toxic wastes. Much of the blame can be placed on industrial activities in developed (affluent) countries over the last half century. In fact, various reports have shown that affluent societies account for more than 75 percent of the world's energy and resource consumption and also create most of the industrial, toxic, and consumer waste.

Overcoming poverty, gender equality, health promotion, environmental conservation and protection, rural transformation, human rights, intercultural understanding and peace, sustainable production and consumption, cultural diversity, and information and communication technologies - these are the key themes under the Global Action Program of the Post-United Nations Decade of Education for Sustainable Development (UNDESD), the ASEAN Environmental Education Action Plan (AEEAP), and the National Environmental Education Action Plan for Sustainable Development for 2018 to 2040.

Education for sustainable development centers on awareness of sustainable development issues, enhancing knowledge, influencing values and attitudes, and encouraging responsible behavior and learning the leads to action. Information is a major component of education and a continuous campaign for massive environmental awareness is indeed essential (Environmental 
Management Bureau - Department of Environment and Natural Resources, 2018).

Implementing a greening program in the university is highly encouraged by the Environmental Management Bureau Department of Environment and natural Resources Region 7. This program may include seedling production/vegetable gardening and marketing, reforestation and/or nursery establishment, establishment of a botanical garden, creation of a herbarium, establishment of a bio-park, holding of green fairs and sale of green products, composting, and establishment of green spaces, to name a few.

University of Cebu Lapu-Lapu and Mandaue (UCLM) has conducted three studies which reveals that greening program is a need in the partner communities that it serves for extension services. In the study of Montecillo and Amparado (2015), Village Hipodromo, Cebu City, Cebu, Philippines, the residents are planting ornamentals in their garden. This reflects the need for the community to plant fruits and vegetables to ensure food security in the village.

The second study is a community profiling conducted by Amparado, Camayra, Dorio \& Patindol (2017), data was collected in 2008 and 2016 in Village Looc, Mandaue City, Cebu, Philippines. The analysis revealed that there were concerns on educational attainment, unemployment, income, the number of children per household, food \& drinking water storage, materials of housing construction, backyard gardening, and livestock raising. In 2008, community extension programs were focused on solid waste management, literacy, and livelihood programs. The survey in 2016 identified sustainable programs for the university which includes solid waste management, health education, literacy, livelihood, greening, livestock raising, and community participation programs. 
The third study, the researchers have identified that the sustainable programs of the university for Village Opao, Mandaue City, Cebu, Philippines shall include literacy, livelihood, backyard gardening, livestock raising, flooding, family planning, administration of tetanus toxoid, and community participation programs (2020).

The study hopes to contribute to the attainment of the university's mission: pursue excellence in instruction, research, and community service towards social and economic development as well as environmental sustainability (Amparado, Gimena, Patindol \& Tan, 2013). However, it is important for the university to ascertain if the greening program is an acceptable, accessible, affordable and sustainable community extension program for the students in the campus. This will ensure that the participants of the program will be motivated in the planning, organization, implementation and evaluation of various activities of the greening program.

\section{Related Studies}

Studies related to greening programs have been conducted in the past. In an article which aims to evaluate the practice of sustainability among Malaysian Secondary Schools involved in the Sustainable Schools Program Environmental Award (SLAAS), the research attempts to identify the SLAAS effects on teachers' and students' behaviors after direct involvement with the activities of the program. A questionnaire survey was administered for 247 teachers and 447 pupils, to evaluate the after effects of the SLAAS. Document analysis was employed to identify the greening activities that were carried out in the schools involved. The results showed that the school's involvement in SLAAS has some transformative effect on the schools especially on greening activities and also on sustainable behavior within the school compound. Based on the correlation analysis, it showed that there was a significant 
correlation between the knowledge about SLAAS program and the behavior of the teachers (Hanifah, Shaharudin, Mohmadisa, Nasir \& Yazid, 2015).

In another study by Galang, the researcher presented a national profile of developments in higher education for sustainable development in the Philippines and to analyze a new initiative to accelerate environmental education for sustainable development within academic institutions. The paper finds that EESD in the Philippines has an official base in the National Environmental Education Plan, which provides a framework to guide higher education. Two national networks promote environmental education, while environmental training and curriculum projects have been supported by government agencies and academic institutions, but without explicit policy support for more widespread changes. In contrast, the Dark Green Schools (DGS) program offers a distinctive "whole institution" approach and accreditation system devised in line with the principles of EESD for coherent systemic change. The design and pilot year of the DGS program shows positive potential for "greening" academic institutions and the issues that arise in seeking curriculum change, future funding and formal support at sector level (2010).

\section{Objectives}

This study is a needs assessment of the greening management program which will be implemented as a community extension program in the Basic Education Department of UCLM.

\section{Methods}

The study utilized the descriptive quantitative design using researcher-made questionnaires. Perceptions from students were gathered using a survey form. The study was conducted at the Basic Education Department of UCLM. Table 1 shows the number 
of respondents who answered the survey forms. For the treatment of the data, frequency, proportion and weighted mean was used.

\section{Table 1. Number of Respondents}

\begin{tabular}{|l|c|}
\hline Basic Education Department & Sample \\
\hline Elementary & 200 \\
\hline Junior High School & 200 \\
\hline Total & 400 \\
\hline
\end{tabular}

\section{Results and Discussion}

This section presents the findings of the study. Eight questions were asked from the respondents of Elementary, while twenty questions were asked from the respondents of Junior High School.

Based on the findings from the Elementary Department, majority of the respondents has not planted in the last 12 months. But they would like to participate in a greening management program.

The students would like to do the following: plant vegetables; take care of fruit-bearing tree seedlings; and take care of plants (cultivating, watering, fencing, controlling of pests, weeding and fertilizing). They would like to do gardening activities from 12:30 PM to 1:30 PM.

For vegetables, they would like to plant talong, sili and monggo. For fruit-bearing plants, they would like to plant mango, avocado and water apple tree. For ornamental plants, they would like to plant rose, gumamela and orchids.

Among the junior high school respondents, majority of the respondents were: aware about the issue on climate change; want 
to become part in the solution of the problem; aware about the greening program; have plants at home; aware that greening management conserves natural resources and the ecosystem; will participate in the greening program; they segregate wastes at home and in the school; have seen students planting in school; aware of organic fertilizers; and are aware of indigenous plants.

However, it was worthy to note that the students: were not involved in planting activities in the last 12 months; have not seen their teachers in planting activities in school; and are not aware of permaculture.

The study also shows that the students rate the present greening status of the department and the university as good. The students would like to plant calamansi. They can afford to take care two plants. They prefer to take care of their plants from 6:00 AM to 7:00 AM.

\section{A. Needs Assessment of the Greening Management Program from the Elementary Department}

1. Have you planted in the last 12 months?

Yes - 79

No - 121

2. Would you participate in a greening program in UCLM?

$\begin{array}{ll}\text { Yes - } & 170 \\ \text { No - } & 30\end{array}$


3. Which of the following activities for gardening would you like to do? (multiple response)

Buy plants

Making a compost

Propagating plants

Making a garden plan

Planting vegetables

Planting ornamental plants

Taking care of fruit-bearing tree seedlings

Taking care of plants

$\begin{array}{ll}- & 117 \\ - & 88 \\ - & 89 \\ - & 140 \\ - & 170 \\ - & 118 \\ - & 147 \\ - & 143\end{array}$

4. When would you like to do gardening activities?

7:15 AM-7:30 AM - 67

3:45 PM-4:45 PM - 63

12:30-1:30 PM - 70

5. Which of the vegetables below would you like to plant? (multiple response)
A. Sili
$-109$
B. Sitaw
$-55$
C. Patola
- $\quad 31$
D. Talong
$-132$
E. Pechay
$-88$
F. Ampalaya
$-82$
G. Upo
- 27
H. Okra
I. Kamatis
- 99
J. Monggo
- 102
K. Malunggay $\quad-98$
L. Onion Springs - $\quad 48$ 
6. Which of the ornamental plants below would you like to plant? (multiple response)
A. Rose $\quad-187$
B. Anthurium $\quad-\quad 23$
C. Gumamela $\quad-\quad 129$
D. Snake Plant $\quad-\quad 88$
E. San Francisco - 71
F. African Daisy - 77
G. Santan $\quad-100$
H. Cactus $\quad-\quad 211$
I. Orchids $\quad-98$
J. Aloe Vera $\quad-\quad 85$
K. Aster $\quad-11$

7. Which of the following fruit-bearing plants would you like to nurse?
A. Santol tree
- 83
B. Mango tree
- 181
C. Guava tree
- 92
D. Jackfruit tree
- 195
E. Bread fruit tree
- 28
F. Water Apple tree
- 134
G. Chico tree
- 172
H. Pomelo tree
- 43
I. Avocado tree
- 139
J. Calamansi
- 100
K. Star apple tree
- 171 


\section{B. Needs Assessment of the Greening Management Program from the High School Department}

1. Are you aware about the issue on climate change?

Yes $\quad-\quad 98.8 \%$

No $\quad-\quad 1.2 \%$

2. Do you want to become part of the solution of this issue?

Yes $\quad-\quad 84.9 \%$

No $\quad-\quad 15.1 \%$

3. Are you aware about greening management program?

Yes $\quad-\quad 67.4 \%$

No - $\quad 32.6 \%$

4. Have you been involved in planting activities in the last 12 months?

Yes $\quad-\quad 35.7 \%$

No $\quad-\quad 64.3 \%$

5. Do you have plants at home?

Yes $\quad-\quad 88.3 \%$

No $\quad-\quad 11.7 \%$

6. Are you aware that greening management conserves our natural resources and ecosystem?

Yes $\quad-\quad 76.9 \%$

No $\quad-\quad 23.1 \%$ 
7. If your department will implement a greening management program, will you participate in the program?

Yes $\quad-\quad 68 \%$

No $\quad-\quad 32 \%$

8. Do you have a composting pit at home?

Yes $\quad-\quad 34.5 \%$

No $\quad-\quad 65.5 \%$

9. Do you segregate wastes at home?

Yes $\quad-\quad 76 \%$

No $\quad-\quad 24 \%$

10. Do you segregate wastes in the school?

Yes $\quad-\quad 75.7 \%$

No $\quad-\quad 24.3 \%$

11. Have you seen your teachers do planting activities in school?

Yes $\quad-\quad 40.6 \%$ n

No $\quad-\quad 59.4 \%$

12. have you seen students do planting activities in school?

Yes $\quad-\quad 64 \%$

No $\quad-36 \%$

13. Are you aware of organic fertilizers?

Yes $\quad-\quad 76.3 \%$

No $\quad-\quad 23.7 \%$ 
14. Are you aware of permaculture?

$\begin{array}{lll}\text { Yes } & - & 62.2 \% \\ \text { No } & - & 37.8 \%\end{array}$

15. Are you aware of indigenous plants?

Yes - $\quad 61.8 \%$

No - $\quad 38.2 \%$ 
16. If you were to rate how green the High School Department is, what is your rating?

$\begin{array}{lll}\text { Excellent } & - & 11.7 \% \\ \text { Very Good } & - & 24.9 \% \\ \text { Good } & - & 38.8 \% \\ \text { Fair } & - & 15.4 \% \\ \text { Poor } & - & 9.2 \%\end{array}$

17. If you were to rate how green the entire university is, what is your rating?

$\begin{array}{lll}\text { Excellent } & - & 15.4 \% \\ \text { Very Good } & - & 31.7 \% \\ \text { Good } & - & 32.3 \% \\ \text { Fair } & - & 15.4 \% \\ \text { Poor } & - & 5.23 \%\end{array}$

18. If you are given the chance to plant today, what plant will you choose to care?

Bamboo plant

Calamansi plant

Golden Duranta

San Francisco

Other Ornamental plants
- $\quad 28.3 \%$

- $\quad 30.2 \%$

$-\quad 7.4 \%$

$-17.5 \%$

- $\quad 16.6 \%$ 
19. How many plants can you afford to care?

$\begin{array}{lll}1 & - & 26.2 \% \\ 2 & - & 26.5 \% \\ 3 & - & 23.1 \% \\ 4 & - & 4.6 \% \\ 5 & - & 19.7 \%\end{array}$

20. When is the best time you can extend to take of your plants?

6:00 AM-7:00 AM - $39.7 \%$

3:00 PM-4:00 PM - $27.4 \%$

4:00 PM-5:00 PM - 32.9\%

\section{Conclusion}

Based on the findings of the study, the students of the Basic Education Department accept the greening management program and are willing to participate in this program.

\section{Literature Cited}

Amparado, M. A. P., Camayra, M. T., Dorio, P. A. Jr., \& Patindol, D. B. (2017). Sustainable community extension programs for Village Looc, Mandaue City, Cebu, Philippines: The $8^{\text {th }}$ year re-assessment, IAMURE Multidisciplinary Research, 19(1), 102-114.

Amparado, M. A. P. \& Colonia, G. E. (2020). Community Needs Assessment of Village Opao, Mandaue City, Cebu Journal of Teacher Education, 1(1), 83-100.

Amparado, M. A. P., Gimena, J. A. F., Patindol, D. B. \& Tan, R. D. (2013). University of Cebu Research Center Manual. Philippines: University of Cebu. 
Environmental Management Bureau - Department of Environment and Natural Resources. (2018). 2019 National search for sustainable and eco-friendly schools. Philippines: EMBDENR.

Galang, A. P. (2010). Environmental education for sustainability in higher education institutions in the Philippines. International Journal of Sustainability in Higher Education, 11(2), 173-183.

Hanifah, M., Shaharudin, I., Mohmadisa, H., Nasir, N., \& Yazid, S. (2015). Transforming sustainability development education in Malaysian schools through greening activities. Review of International Geographic Education Online, 5(1), 77-94.

Montecillo, C. P. V. \& Amparado, M. A. P. (2015). Community Health Needs of Barangay (Village) Hipodromo, Cebu City, Cebu, Philippines. Journal of Research in Nursing, 1(1), 2029.

Robbins, S. P. \& Coulter, M. (2001). Management. $6^{\text {th }}$ edition.

Philippines: Pearson Education Asia Pte Ltd. 